\title{
Feeling 'the thing': Women and a National Literature Enter the Academy
}

\author{
Mary Polito
}

\section{Les femmes et une littérature nationale entrent à l'Académie}

Quellien peut-onétablir entreles femmes et la langueanglaise? Comment $l^{\prime}$ arrivée des fernmes dans l'académie littéraire coincide-t-elle avec l'institutionalisation de la littérature anglaise? Polito suggère que les femmes et la littérature anglaise ont toutes deux reçu la tâche de «civiliser la nation». Pour les «pères» de l'université - Matthew Arnold en Angleterre et Daniel Wilson à l'Université de Toronto - la littérature anglaise n'avait qu'une fonction utilitaire: servir de médium pour une forme particulièrement raciale de nationalisme. La première génération d'étudiants et de professeurs de littérature anglaise était appelée par Arnold à «propager le meilleur qui existe» pour le bien de la nation et à remplir leur devoir en répandant le génie de l'anglais. La position des femmes en cette période fondatrice était complexe car en même temps qu'elles faisaient leur entrée à l'université et qu'elles défiaient la domination des hommes dans le domaine de la critique littéraire, on leur faisait comprendre qu'elles devaient être des servantes et des anges, des muses pour les vrais critiques. La question qui se pose est la suivante: est-ce que les femmes pouvaient ressentir «la chose», la vérité $d u$ Canon anglais au coeur du corps bourgeois et impérialiste?

In A path not strewn with roses: One Hundred years of women at the University of Toronto, Anne Rochon Ford describes the resistance at University College to the entrance of the first female undergraduates. The men themselves, Rochon Ford notes, vigorously protested the admission of women, and when they arrived, they took pains to make them feel most unwelcome. Even when they were granted admission, they were forbidden to attend lectures and had to employ private tutors. The first professor of English at U of T - Daniel Wilson - was particularly opposed to the presence of women. Rochon Ford relates an interesting anecdote about Wilson: a close friend of George Brown and his family, Wilson made a bet with one of Brown's daughters that "if she reached his own height he 
would let her attend his lectures. She did....and as a concession Wilson allowed her to sit in his adjoining office with the door open when he was lecturing. She could thus hear the lectures withoutbeing seen by the male students" (11-12). The point was clearly not only that women should not study, but that the studies of the men should not be disrupted and would be disrupted by the presence of the 'feminine.' Yet English Literature itself, like the woman scholar, had been newly admitted to the university as an academic subject amid much anxiety and some protest. Women and 'English' have been married, in fact, from these concurrent initiatory moments, and women still make up the majority of 'English' undergraduate students in most Canadian universities. I offer evidence here that both women and 'English,' in the crises of these founding moments, were given the task of being carriers of a particularly racialized form of nationalism-a kind of 'bionationalism' - in those countries with present or past ties to the British Empire, that the woman educated in the literature of her nation was to absorb its civilizing, biologically-felt powers and transmit them intuitively to those she was to bare and nurture.

"Reading English," at English-speaking universities, argues Chris Baldick in The Social Mission of English Criticism: 1848-1932, first took the form of "ritual contact" with English authors and was initiated amidst a generalized deployment of the forming canon as "a museum of national genius" (82), an egalitarian dispersement of noble Englishness. The operation can be seen, on the contrary, in the words of Michel Foucault on the function of the author in Western cul ture, as "the principle of thrift in the proliferation of meaning" ("Author" 159). The "subjection" of English writing was a strategy of rarefaction, a form of censorship, a way "to reduce the great peril, the great danger with which fiction threatens our world" (158).

The accrued value produced through such "thrifty principles," was in turn invested in "anatomoco-politics" (the individual, its body and its intrinsic rights) and "biopolitics" (the population, nation, race, species). The individual and the nation, born together in the early modern period through juridico-political technologies, were now underwritten by a new discourse of sexuality: "the biological and historical [were]...bound together in an increasingly complex fashion" (History 151-2). From its founding moment, 'English' functioned to censor what might threaten nationalist interests; however, it also contributed to the production of a nationalized and racialized bourgeois body whose "own sex was something important, a fragile treasure, a secret that had to be discovered at all costs" (121). 
Foucault argues that the "idle" upperclass woman was "...the first figure to be invested by the deployment of sexuality...[she] inhabited the outer edge of the 'world' in which she always had to appear as a value" (121). Early women scholars, with sometimes radical educational ambitions, were being contained by institutions within manageable, conservative parameters; they were being kept in residences on the actual "outer edges" of the campuses and, like George Brown's daughter, on the periphery of the classroom. Their eroticized, racialized bodies were at the same time being disbursed in the interest of a class which was reinventing itself as a racially charged anatomy.

Although debates about the place of both women and English Literature in the academy were taking place simultaneously in the U.S., Australia, Canada and England, nowhere was the resistance to changes to the status quo so great, (nor the debates so well-documented), as at Oxford and Cambridge. This is the site to which I turn my attention here-I offer it as a kind of paradigmatic debate, versions of which were conducted under localized conditions elsewhere. ${ }^{1}$

In mid-nineteenth-century England, literacy was rising rapidly and the book, popular novel and serial trade were expanding at an unprecedented rate. Some of these popular publications dealt with contemporary issues and among a plethora of effects, they contributed to the interpellation of 'the discontented' at a time when class conflict had erupted into violent confrontation and the spectre of revolution hovered over the thrust for change in England. Women, too, were highly active in calling for change, not the least of their actions being directed on behalf of their own right to move into the public world through suffrage and education. Baldick reads events such as class unrest and the suffrage movement as threats requiring discipline, diversion or most preferably appropriation in the interest of the status quo and for him, the chief stock broker in this investment strategy is the poet, literary critic and school inspector Matthew Arnold.

Into the cultural fray of restless workers and women reading and thinking for themselves in what was clearly for some an alarming manner, Arnold appears with a program which he claimed would facilitate the proliferation of productive literary experience: "'We have to turn to poetry to interpret life for us, to console us, to sustain us. Without poetry, our science will appear incomplete; most of what passes with us for religion and philosophy will be replaced by poetry" (Baldick 19). 
Arnold's goal was to create a climate in England where the Classics could be born again and to this end, he formulated an extensive list of shoulds and should nots (mostly should nots), for writers and critics to enable them to cultivate this cultural growth. Finally, for Arnold, the function of criticism was to prepare and precede, Moses-like, for the promised land of a new English literature, in what is identified as the Arnoldian "doctrine of postponement," expressed by Arnold as "force till right is ready." Arnold's ideas about criticism and creativity as storage and investment would soon inspire the ideal of a truly national literature. These ideas would dominate the teaching of English literature for fifty years just as they still linger in certain assumptions about reading and writing on 'the greats.'

That English Literature was to fulfil a disciplinary function is made obvious in Arnold's most radically conservative theorizing about the British school system, in which he and his followers saw the purpose of education to be the protection of society. Arnold compared schools with prisons as guarantors of social stability (Baldick 63), while other educators went so far as to compare teachers to soldiers. The Reverend Canon Browne, an extension lecturer, referred to "the civilizing, softening charms of the noblest literature in the world"' (Baldick 65) and York Training College instructor H.G. Robinson makes explicit the relation of literature to the constitution of the disciplined 'English' body when he calls literature a "cure: a homeopathic treatment" (Baldick 65).

It is not surprising that English as "medicine" was first taught, not at the universities, but at sites that served the adult education movement such as the Mechanic's Institutes, the Working Men's Colleges and the extension lecture circuit. Educator James Hale argued that "lectures on literature to mechanics would make them less open to corruption by the abundance of cheap sensational fiction then coming into circulation" (Palmer 34), and that literature would "promote sympathy and fellow feeling among all classes" (Baldick 62). Extension lecturer J.C. Collins summarizes this pedagogical philosophy in The Study of English Literature, published in 1891:

[The people] need political culture, instruction...in what pertains to their relation to the State, to their duties as citizens; and they need also to be impressed sentimentally by having the presentation in legend and history of heroic and patriotic example brought vividly and attractively before them. (Baldick 64-65) 
At the same time, the East India Company began examining candidates applying for the most prestigious posts in the Empire and foremost among the examinations was the one in English literature. It was hoped, according to a document formulated by the committee on examinations, that "a taste for pleasures not sensual" would enable the officers in the colonies to resist "scandalous immorality" (Baldick 70). Thomas Babington Macaulay, as a member of the Supreme Council of India, articulated the rationale for such an education for imperial officers: "...we ought to fill the magistrates of our Eastern Empire with men who may do honour to our country, with men who may represent the best part of the English nation" (Baldick 70-1). English Literature was also recommended for the education of imperial subjects because, quoting the same document, "to trade with civilized men is infinitely more profitable than to govern savages" (71). The institutionalization of English literature as subduer of class unrest, civilizing tool for imperial subjects and instrument of diffusion of the sensual temptations to be withstood by imperial officers is clearly a gesture of "thriftiness" masquerading under the guise of expansion.

Baldick demonstrates how the discourse of literary criticism has, from Plato, carried "more than just traces of other discourses, notably the economic, political and judicial" (9). A close reading of Arnold's treatise, "The Function of Criticism at the Present Time" (1864), shows how, for Arnold, criticism is also related to systems of thinking about human biology. In particular, he appropriates a lexicon related to female sexuality and reproduction to describe the processes of his ideal literary criticism. The "thrifty principles" Arnold proposes and administrates clearly generate a profit which is then reinvested in the discourse of secret truth connecting the biological and the literary. At the same time, Arnold marks the bodies of real women as devalued, polluting objects, counterproductive elements to his project of producing a truly English golden age.

Arnold militates against a criticism that concerns itself with worldly matters, that is "interested"; such a critical attitude results in such uncomfortableeventsas theFrench Revolution. Instead, Arnold instructs his readers: "real criticism obeys an instinct...[it is] a pleasure in itself...an object of desire" (17); feminized, criticism is to function maternally, as an incubator for the literature to come, as the "disinterested endeavour to learn and propagate the best that is known and thought in the world" (28). "Ideas" here function paternally, as the insemination of criticism, and 
Arnold calls English criticism to exogamous relations with European ideas in order to strengthen the stock of English intellectual life, which he figures as particularlybarren in his time. In order to produce "thenational glow of lifeand thought" (12), helooks for "[f]lutterings of curiosity, in the foreignsense of the word, [to] appear amongst us" (17).

Arnold argues that there are no journals in England capable of propagating such fertile ideas and he cites as evidence a newspaper account of a young woman workhouse worker who is arrested for the murder of her illegitimate child; the article concludes: "Wragg is in custody" (21). Arnold complains, in answer to those self-satisfied writers who call the English the "best breed in the world": "Wragg! If we are to talk of ideal perfection...has any one reflected what a touch of grossness in our race.... is shown by the natural growth amongst us of such hideous names, - Higgingbottom, Tiggins, Bugg [and Wragg]" (21). He argues that criticism must avoid comment on such mundane, "practical" and "gross" matters. To do so would be like so much inbreeding.

Wragg, her name, her position, her desperate crime are barred from representation in Arnold's universe. Instead, in order to describe the processes of his beloved criticism, Arnold appropriates language associated with a positive representation of her reproductive function and her female sexuality. As a critic and poet himself, Arnold wants to experience "quickening," to feel life, to be pregnant with English meaning, to give birth to that compelling secret. Likewise, he issues an injunction to other critics to "propagate the best that is known and thought in the world" (28).

The "propagation" of truth by the bourgeois critic is figured in the rhetoric of biology, just as imperialism can be read as a means of biological invasion through literature. Foucault correlates this "concern with the body and sex to a type of 'racism'... a racism of expansion" (History 125), which appeared in the second half of the nineteenth century in its modern "biologizing, static form" (149). So the English author, "his" literature and the hermeneutic it required, coalesced in the production of the new Englishman, a race and a class invested with a powerful knowledge at its very core. It stood to reason that such an English Literature should find its way into the most prestigious educational institutions of the state - the universities.

Nevertheless, the campaign for the establishment of English schools at Oxford and Cambridge was marked by a multitude of anxieties. As Baldick notes, there was a fear that the discipline would degenerate into 
"chat about Shelly," and many predicted that it would become "a useful dumping ground for weaker classics students ... women ... and the second and third rate men who were to become school masters" $(73,74)$. At Cambridge, English entered the academy in 1878, attached to the Board of Medieval and Modern languages. The second Professor of English at Cambridge (and the first to hold the position long enough to develop the discipline) was Sir Arthur Quiller-Couch, (who was and is known widely as simply ' $Q$ '). His inaugural lecture demonstrates his die-hard adherence to Arnoldian principles, just as his rhetoric betrays his experience of literature as a biological secret. As he speaks, he holds and quotes from volumes of Shakespeare, Milton, Gray and Keats. He calls for:

...the study of such definite beauties as we can see presented ... under our eyes ... why worry me with any definition of the Grand Style in English, when here, and again here - in all these lines, simple or intense, or exquisite or solemn - I recognize and feel the thing. - (Baldick 81, emphasis mine)

Q. felt the truth of the text at the core of his bourgeois body; a truth so essentially secret it could barely be articulated. He set forth no pedagogical strategy, converted, like Walter Raleigh, his counterpart at Oxford, to what Baldick calls the "cult of heroic worship" (82).

The birth of the woman scholar did not take place without tireless lobbying by figures like Emily Davis whose polemic on this issue - The Higher Education of Women - was published in 1869. The 1988 edition contains a useful introduction by Janet Howarth which places Emily Davis historically within the debates on the 'woman question.' Davis was involved with a large group of highly political women working for change in the areas of property law, suffrage, and the general expansion of opportunities for women in the world. She was the editor of Victoria Magazine, a printing firm staffed by women for the publication of articles on women's education and employment.

The Higher Education of Women is an eloquent treatise on the suitability of women for higher education and Davis' rhetorical strategies demonstrate that she was an early feminist reader of literature. For example, she takes issue with the commonplace assumption that women "ought to be made what men want" in terms that would dictate their educational program (17). By examining quotations from Coventry Patmore, Tennyson and Shakespeare to demonstrate that there is no consistency 
in this figure of "what men want," she argues that therefore this should not logically be the basis upon which women's pedagogical program is designed.

She conducts a fascinating discussion of the question of 'nature,' bidding for "a frank recognition of the fact, that there is between the sexes a deep and broad basis of likeness. The hypothesis that men and women are essentially and radically different, embarrasses every discussion" (163-4). She observes that occupations in which both sexes take part do no harm to either women or men, citing as an example how "Miss Yonge and Mrs. Oliphant help Mr. Trollope in supplying the world with novels and it is not thought necessary to guard either party from writing masculine or feminine novels respectively" (186-7).

While Davis attempts to appease her male readers by quoting from Elizabeth Barrett Browning's "Lady Geraldine's Courtship" concerning the charms of conversation with an educated woman, she also takes to task the enemies of women's advancement, such as Charles Kingsley, a detractor of the women's suffrage movement who predicted that their success would

cause a widespread revolution in society, of which the patent danger will be, the destruction of the feeling of chivalry and the consequent brutalization of the male sex. (178)

Davis answers Kingsley's defense of a system under which wives remained under complete legal authority of their husbands by quoting his own literary work, Hereward the Wake, in which a young wife is led to return force with force to protect herself against a husband who beat her. She calls for the dethronement of the law of force so that the protection of women through the power of their husbands would not be necessary.

Davis' interpretive practice is undoubtedly an example of the dangerous proliferation of "interested" and practical meaning against which figures like Arnold had been militating: she appropriates the cultural authority of literary works to strengthen her position both logically and rhetorically. Despite Davis' clever appropriation of literature for her political project, however, when she achieved her end and saw women enter the academy, it would be English Literature which would be assigned the task of 'keeping' women in the manner to which they and their men had been accustomed.

The precedent concerning women and literary studies had been set as early as 1848, when Queen's College for Women was founded and where 
literature was established as a formal object of study, as a corrective to what educators saw as women's easy stimulation by popular fiction. Baldick argues that "many of the movement's promoters saw their job in fact as a 'homeopathic' attempt to forestall any more profound change in women's traditional position" (68). As Queen's College founder F.D. Maurice bluntly asserts, "[women] need education, not only to show them what they can do, but what they cannot do and should not attempt" (Baldick 68). To this end, English was seen as a healthy alternative to the suggestion that women take degrees in medicine. Instead,

...women should be initiated into the thoughts and feelings of her countrymen in every age...that knowing the hearts of many...she may be able to comfort the hearts of all. (Baldick 69)

On this theme, Charles Kingsley, (whom we met above), in his introductory lecture as Professor of English at Queen's College, suggested that the study of English would

quicken women's inborn personal interest in the actors of this life drama...for God intended women to look instinctively at the world. Would to God that she would...fulfil to the uttermost her vocation as priestess of charity! (Palmer 38)

To educate women in English Literature was to encourage them to do what they naturally did best: to "feel the thing." Having felt it, they were to lovingly teach others to feel it; in the "cult of heroic worship," they would then earn the title of "priestess."

The first college for women was constructed near Cambridge in 1873; in 1879, two colleges were established at Oxford. Women could now attend classes and take exams, although they would not be granted degrees until 1920 at Oxford and 1948 at Cambridge (Rochon Ford 4). When English was established at the universities a few years after the entrance of women, women did indeed make up the majority of students in English classes; between 1897 and 1901 there were 87 candidates in English at Oxford, 69 women and 18 men (Baldick 69).

The rhetoric of the early English critics at Oxford and Cambridge certainly suggests the presence of some kind of disturbance, of a taboo and a temptation which both enabled and threatened the operations of the discipline. The idealized function of women in relation to literature is evident in Quiller-Couch's description of the relation of Dorothy Wordsworth to her brother and Coleridge. He calls her "the good angel 
of them both...[the] inspiring handmaid of some of the greatest poetry in our language" (Studies in Literature 58, 71). Q. states further of her relation to William, "she touched his lips and, through him she has left her benign influence upon all later Romantic poets, to this day" (Studies 91). Dorothy Wordsworth is a "priestess," an "angel," a highly charged being, an untouchable object of incestuous desire. Like her, women in the field of literary criticism were to be angels and handmaids, erotic, but benign because untouchable and most of all inspiring to those males with whom they made their influential contact.

Q.'s lectures also demonstrate the effect of certain disturbing contradictions produced by the presence of the feminine "angels" before him. $\mathrm{He}$ consistently assumes a male audience, although according to the numbers at Cambridge, the faces before him were mostly female. He announces: "your college gown is a toga virilis, and you have come to the age to wear it" (Lecture on Lectures 37), and he extols the value of the tutorial system with its method of "a man reading with a man" (26). In describing the purpose of the establishment of the English school, he informs his students that it was "to train men of your age in understanding" (Lecture 149). As to lectures, Q. asserts:

of women candidates for our English Tripos at Cambridge I can scarcely remember one in these fourteen years who did not frequent too many lectures.... In short, over-indulgence in being lectured-to is a primrose path to intellectual sloth, the more fatally deceitful because it looks virtuous. (28)

Although his lectures consistently exclude any recognition of the women before him, his rhetoric here betrays the associations he has been making. Women are sensual, they take the easy route - down primrose paths, and are self-indulgent. They may look virtuous on the outside but this is deceit. Inside, they are slothful and passive; inside they harbour the dark secret of their sexuality.

Sir Walter Raleigh, at Oxford, soon suffered from serious disillusionment with the enterprise of teaching English and his anxiety is clearly related to his fears about his own masculinity. He complains:

I can't help feeling that critical admiration for what another man has written is an emotion for spinsters...if I write an autobiography it shall be called 'confessions of a pimp'.... The eunuch was the first modern critic. - (Baldick 78, 79) 


\section{Feeling 'the thing' $\cdot 51$}

His difficulty was perhaps to do with the problem of teaching at an institution which had traditionally been defined as promoting manly enterprises, a subject which was seen to be, like the women in the lecture hall before him, a softening, tempering, sensualizing influence. He himself, through his association with this combination of contaminants, is feminized, as a "spinster" and a "eunuch," and socially degraded as a "pimp." Raleigh attempts to position himself, a heterosexual male critic, as conqueror of intellectual territory that is gendered female, when he asserts: "[t]he world of perception and will, of passion and belief, is an uncaptured virgin" (Palmer 123). The homoerotic association inherent in the idea of uncaptured virgins - the scholars before him - capturing an uncaptured virgin was perhaps too much for Raleigh. He gladly abandoned literature for the battlefield of the Great War, where he was to write virile anti-German propaganda.

One hundred years after these events, many of us in 'English' like to think that we have not been entirely contained by the discursive injunction through which Arnold called us to go forth like imperial officers and "propagate the best there is" for the good of the nation. Other legacies have contributed to what Judith Butler calls a "conflicted cultural field" (145), where a reinscription of the constraining discourses of our invention has occurred. As women scholars, we often figure feminism as just such a mode of reinscription and experience our post-secondary education as contributing to the process of our liberation. And yet, our desire, our intellectualized but corporeal response to the texts we study (feeling "the thing") is no doubt implicated in our discursive relation to Arnold - we are his critical heirs (the objects of his propagation). As such heirs, it behooves us to maintain a vigorous interrogation of our heritage. Is the very concept of 'national literature' inevitably inscribed inside a colonialist paradigm? Does the institutionalization of education for women, particularly in the humanities, continue to function as a means to "show women what they cannot do and should not attempt" (despite, or even through, the operations of feminism) and as a thrifty and interested investment of femininity in the nurturance of the liberal arts? How can we contribute to the conditions of possibility in which 'fiction,' or more broadly representation, could do its work as the "great peril" which threatens the world as we know it? How can we unleash peril on the two most enduring and interdependent "legal fictions" of modern times: the individual and the nation? 


\section{Notes}

1 For an overview of the early history of the "higher education" of women in Canada see: Anne Rochon Ford's A path not strewn with roses: One Hundred Years of Women at the University of Toronto 1884-1984 (Toronto: U of Toronto $P$, 1985) and Jo LaPierre's "The Academic Life of Canadian Coeds" in Gender and Education in Ontario, Ruby Heap and Alison Prentice, eds. (Toronto: Canadian Scholars' Press, 1991). Each of these works provides an extensive list of primary documents. For an introduction to the early years of "English" at Canadian universities, see Robin S. Harris's English Studies at Toronto: A History (Toronto: $U$ of Toronto $P, 1988$ ). Harris also includes a useful bibliography.

\section{Works Cited}

Arnold, Mathew. Matthew Arnold's Essays in Criticism: First Series. Ed. Sister Thomas Marion Hector. Chicago: U of Chicago Press, 1968.

Baldick, Chris. The Social Mission of English Criticism 1848-1932. Oxford: Clarendon Press, 1983.

Butler, Judith. Gender Trouble. New York: Routledge, 1990.

Davis, Emily. The Higher Education of Women, (1866). Ed. Janet Howarth. London and Ronceverte: The Hambledon Press, 1988.

Foucault, Michel. The History of Sexuality Volume I: An Introduction.

Trans. Robert Hurley. New York: Vintage Books (Random House Books), 1980.

_. "What Is An Author?" Textual Strategies: Perspectives in

Poststructuralist Criticism. Ed. Josue Harari. Ithaca: Cornell UP,1979. Palmer, D.J. The Rise of English Studies: An Account of the Study of English

Language and Literature from its Origins to the Making of the Oxford

English School. London: Oxford UP, 1965.

Quiller-Couch, Sir Arthur ("Q"). A Lecture On Lectures. New York: Haskell House Publishers, 1974.

—. Studies in Literature. Cambridge: Cambridge UP, 1948.

Raleigh, Sir Walter. On Writing and Writers. Ed. George Gordon. New York: Books for Libraries Press, 1926.

Rochon Ford, Anne. A path not strewn with roses: One Hundred years of women at the University of Toronto 1884-1984. Toronto: U of Toronto Press, 1985. 